\title{
Desperately seeking niches: Grassroots innovations and niche development in the community currency field
}

\author{
Gill Seyfang*, Noel Longhurst \\ $3 S$ (Science, Society and Sustainability) Research Group, School of Environmental Sciences, University of East Anglia, Norwich Research Park, NR4 7TJ, UK
}

\section{A R T I C L E I N F O}

\section{Article history:}

Received 14 August 2012

Received in revised form 13 February 2013

Accepted 17 February 2013

\section{Keywords:}

Grassroots innovations

Innovation diffusion

Innovation niches

Social innovation

Complementary currencies

Community currencies

\begin{abstract}
A B S T R A C T
The sustainability transitions literature seeks to explain the conditions under which technological innovations can diffuse and disrupt existing socio-technical systems through the successful scaling up of experimental 'niches'; but recent research on 'grassroots innovations' argues that civil society is a promising but under-researched site of innovation for sustainability, albeit one with very different characteristics to the market-based innovation normally considered in the literature. This paper aims to address that research gap by exploring the relevance of niche development theories in a civil society context. To do this, we examine a growing grassroots innovation - the international field of community currencies - which comprises a range of new socio-technical configurations of systems of exchange which have emerged from civil society over the last 30 years, intended to provide more environmentally and socially sustainable forms of money and finance. We draw on new empirical research from an international study of these initiatives comprising primary and secondary data and documentary sources, elite interviews and participant observation in the field. We describe the global diffusion of community currencies, and then conduct a niche analysis to evaluate the utility of niche theories for explaining the development of the community currency movement. We find that some niche-building processes identified in the existing literature are relevant in a grassroots context: the importance of building networks, managing expectations and the significance of external 'landscape' pressures, particularly at the level of national-type. However, our findings suggest that existing theories do not fully capture the complexity of this type of innovation: we find a diverse field addressing a range of societal systems (money, welfare, education, health, consumerism), and showing increasing fragmentation (as opposed to consolidation and standardisation); furthermore, there is little evidence of formalised learning taking place but this has not hampered movement growth. We conclude that grassroots innovations develop and diffuse in quite different ways to conventional innovations, and that niche theories require adaptation to the civil society context.
\end{abstract}

(c) 2013 Elsevier Ltd. All rights reserved.

\section{Introduction}

The challenges of sustainable development are increasingly seen as demanding fundamental change and systemic transformation in socio-technical systems (Jackson, 2009; UKERC, 2009). An immediate example of this need for socio-technical transformation is presented by the recent financial crisis, which has focused attention on the need for more sustainable and resilient monetary systems. Fundamental questions are being asked about the suitability of capitalist debt-fuelled economic growth to sustain local economies (Mellor, 2010), and alternative models are sought which go beyond incremental reforms to offer radically different

\footnotetext{
* Corresponding author. Tel.: +44 1603592956.

E-mail addresses: g.seyfang@uea.ac.uk (G. Seyfang),n.longhurst@uea.ac.uk (N. Longhurst)
}

systems of exchange based on greater transparency and democratic control, as well as environmental sustainability (Spratt et al., 2009).

In recognition that systems exhibit 'lock-in' and 'pathdependency', a growing body of research seeks to understand the dynamics and governance of system-wide transformations and social change for sustainability; an academic literature around coevolutionary systems innovation has emerged which terms these shifts 'sustainability transitions' (Grin et al., 2010). From historical case studies of socio-technical transformations, this work points to the transformative potential of accumulations of experimental projects in 'niche' spaces, as sources of radical (rather than reformist) innovation (Schot et al., 1994). Niches are protected spaces where projects can develop away from the normal selection pressures of mainstream systems, offering supportive networks to allow experimental new systems to take shape, such as business incubators, subsidised technologies, or ecovillages (Smith and 
Raven, 2012). The transitions literature examines the conditions and characteristics of successful (i.e. influential) niches. However, most of this research has focused on top-down technological innovation in market settings; in contrast, "the role of consumers and grassroots initiatives in transitions is underrated and underconceptualised" (Grin et al., 2010: 331).

There is an increasing interest in harnessing the innovative potential of civil society to address policy objectives (NESTA, 2009; McCarthy, 2010; Mulgan, 2006). The UK Government has recently affirmed its view that "the third sector shapes the future by mobilising and inspiring others [and] the innovation and enthusiasm of civil society is essential in tackling the social, economic and political challenges that the UK faces today" (DEFRA, 2012: 2). However, little is known about the conditions required for their success or wider diffusion, or about how these initiatives might be supported to achieve wider influence on mainstream systems. Recent work on 'grassroots innovations' argues that civil society is a promising but under-researched site of innovation for sustainability (Seyfang and Smith, 2007). This work extends the focus of sustainability transitions research to examine predominantly social, community-led, values-driven innovations and explore how to harness and diffuse radical community-based action for sustainability (Seyfang, 2009; Seyfang and Haxeltine, 2012; Hielscher et al., 2013; Georg, 1999; Hess, 2007; Avelino and Kunze, 2009). This paper adds directly to the emerging body of research on grassroots innovations, by using the empirical example of community currencies to test the relevance of niche development theories in a civil society context.

Community currencies are civil society-led parallel exchange mechanisms designed to promote sustainable development. The number of community currency experiments has expanded over the last 30 years (Seyfang and Longhurst, 2013), and within the literature they are often considered as a single movement (Blanc, 2012; Collom et al., 2012). They can therefore be described as grassroots innovations, however they have not previously been studied as innovative niches. This paper explores the extent to which niche development theories can provide an explanation of the growth of the field. Our overarching aim is to gain a better understanding of the processes by which grassroots innovations develop and diffuse, and thereby gain insight into how to harness and grow such initiatives. In order to do this we draw on new empirical research that investigates the global scope and character of community currencies, using primary and secondary sources, elite interviews and participant observation in the field.

The paper proceeds as follows: the next section introduces the theoretical context for this research, highlighting the distinctiveness of grassroots innovations. We then present community currencies as an example of such initiatives, explaining their rationale and application, outlining our research methodology, and describing the growth of the field. Next we explore the extent to which niche processes can be discerned in the community currency field. We conclude with suggestions for future research into grassroots innovations, along with theory-driven recommendations for harnessing their potential.

\section{Theoretical context}

\subsection{Sustainability transitions and niche innovations}

The challenge of shifting modern societies to more sustainable development trajectories has prompted a growing academic and policy interest in the governance of socio-technical transitions and sustainable innovations (Grin et al., 2010). This is particularly important when dominant (unsustainable) systems 'lock-in' innovation processes, cannot solve the underlying problems, and exclude alternative visions (Sanne, 2002). A Multi-Level
Perspective of sociotechnical systems change attempts to explain the dynamic relationships between innovative radical niches, incumbent regimes (dominant systems), and wider landscape pressures (semi-exogenous contexts) (Smith et al., 2005, 2010; Geels, 2002). Historical studies of socio-technical systems transformations have revealed that accumulations of projects in experimental 'niches' have triggered widespread systems-change when those dominant systems have been under tension (Geels and Schot, 2007), and these studies have sought to explain the conditions and processes whereby effective niches might form and influence sustainability transitions in dominant systems.

Sociotechnical niches are defined in various ways in the literature, but a common theme is the 'protected space' where new sociotechnical configurations and practices can be experimented with and develop away from the selection pressures of the dominant regime: "change within the regime tends to be incremental and path-dependent... 'revolutionary' change originates in 'niches"' (Smith et al., 2010: 440). Niches comprise intermediary organisations and actors, which serve as 'global carriers' of best practice, standards, institutionalised learning, and other intermediary resources such as networking and lobbying, which are informed by, and in turn inform concrete projects (experiments) on the ground (Kemp et al., 1998; Geels and Raven, 2006). Under the right regime conditions, successful niches facilitate the diffusion of innovative socio-technical practices and systems. Within this literature Strategic Niche Management has developed as a governance-focused strand of research, which seeks to understand how to proactively create and nurture niches developing desirable sustainable innovations, with the aim of triggering wider systemic transitions (Hoogma et al., 2002; Raven, 2005).

In the strategic niche management literature, Kemp et al. (1998) identify three key elements of successful niche-growth and emergence: visions and expectations; networks; and learning. To best support niche emergence, visions and expectations should be widely shared, specific, realistic and achievable; networking activities should embrace many different stakeholders, who draw resources from their organisations to support the niche's emergence; and learning should contribute not only to everyday knowledge and expertise, but also to 'second-order learning' wherein people question the assumptions and constraints of mainstream systems altogether (ibid). These three processes are, of course, interdependent, and constitute a dynamic niche-development trajectory whereby learning leads to higher expectations of functionality, thereby enrolling new actors and resources, and so on, in either virtuous or vicious cycles (Raven, 2007).

A key empirical question has been how the niche level activity builds on the experience of local experiments, and manifests these learning mechanisms, which in turn support and shape multiple, diverse local projects, and help new projects to form. Building on SNM, it has been suggested that this involves aggregation activities that include:

standardisation, codification, model building, formulation of best practice, etc. Also circulation of knowledge and actors is important, to enable comparison between local practices and formulation of generic lessons: conferences, workshops, technical journals, proceedings, newsletters play a role too. (Geels and Raven, 2006: 378)

This work suggests that the processes of creating shared visions and expectations, networking and learning happen not only at the localised level but also at a more abstract 'global' level. Geels and Raven (2006, 390) suggest that at this level visions and expectations about the functionality of innovations are particularly important. Geels and Deuten (2006) suggest that this 'hidden work' of niche-building consists of three crucial elements: the 
creation of social networks and a sense of community to facilitate information-sharing; intermediary actors who speak for the field and do the socio-cognitive work of knowledge aggregation, and finally the creation of a knowledge infrastructure to enable knowledge flows. The broadening of analysis beyond individual projects and small localised niches has raised questions about the extent to which niche processes themselves are sufficient to lead to the emergence of new technologies and the transitioning of sociotechnical systems (Hoogma et al., 2002; Raven, 2005; Smith et al., 2005). For example, Geels and Raven (2006, 390) suggest that

the niche perspective is not sufficient, because it only highlights internal niche processes. For a complete understanding of nonlinearity and changes in expectations, we need to include external (regime and competitive niche) developments.

The interaction between niche, regime and landscape is a feature of many of the historical case studies that have operationalised the Multi-Level Perspective (e.g. Geels, 2005, 2006), and regime destabilisation has been highlighted as an important opportunity for niche solutions to be adopted more widely: "niche innovations in an embryonic state do not pose a threat to the regime. At some point, external landscape developments may create pressure on the regime and create windows of opportunity for transitions" (Geels and Schot, 2010: 54).

A range of ideal typical possible trajectories and outcomes for niche innovations have been postulated, dependent on different patterns of interaction between niches, regimes and landscapes. Niche innovations might be a source of synergistic reforms to be absorbed into regimes; they might compete with and potentially displace the regime; might expand and work alongside a regime without changing it fundamentally; or could expand to fill a void caused by a regime collapse (Geels and Schot, 2010). Importantly, radical niches need not aim to displace the regime, their aim might be to play a more significant role alongside it, or offer new ideas for incorporation into existing systems - but this work does highlight the importance of regime destabilisation and landscape pressure in creating space for innovative niches to diffuse and increase their influence.

\subsection{Grassroots innovations}

To date, this body of research on sustainability transitions has been applied to cases of principally artefactual socio-technical innovation, in market settings. We turn now to the context of civil society, and innovation in social institutions and arrangements. Seyfang and Smith (2007) argue that community action is a promising but neglected site of innovation for sustainability, and recent work on 'grassroots innovations' addresses this deficit, extending niche innovation analyses into civil society contexts (e.g. Hielscher et al., 2013; Seyfang and Haxeltine, 2012; Witkamp et al., 2011; Smith, 2007; Seyfang, 2009; Georg, 1999; Hess, 2007; Avelino and Kunze, 2009). Grassroots innovations are defined as:

"innovative networks of activists and organisations that lead bottom-up solutions for sustainable development; solutions that respond to the local situation and the interests and values of the communities involved. In contrast to the greening of mainstream business, grassroots initiatives tend to operate in civil society arenas and involve committed activists who experiment with social innovations as well as using greener technologies and techniques" (Seyfang and Smith, 2007: 585).

They include initiatives such as alternative food networks, community energy projects, furniture-recycling schemes, cohousing, ecovillages, low-impact development, Transition Towns, local currencies and so on (Church and Elster, 2002). Importantly, grassroots innovations go beyond individualistic reforms, and seek to build new systems of provision, on the basis of deep green sustainability visions, and collective endeavour and interests (Seyfang, 2009). The distinctive characteristics of grassroots innovations have implications for practice and theory, and we already know something about the ways in which grassroots innovations differ from technological, market-based niches. Grassroots innovations are based in the social economy (rather than the market economy); they tend to focus on social and institutional innovation (rather than technological); they are driven by social need and ideological commitment (rather than profit-seeking); the 'protected space' which supports their development is often one of alternative values and culture (rather than market regulation and subsidies); they are constituted by diverse organisational forms such as cooperatives, voluntary associations, and informal community groups (rather than firms), and they rely on grant funding, volunteer labour, mutual exchange and only limited commercial activity (rather than principally commercial income) (Seyfang and Smith, 2007: 592).

The benefits of grassroots innovations for sustainable development derive principally from their creation of a space for the development of new ideas and practices, for experimenting with new systems of provision, and for enabling people to express their 'alternative' green and socially progressive values, and from the tangible achievement of environmental and social sustainability improvements, albeit on a small scale (Seyfang and Smith, 2007). Conversely, the main challenges faced by grassroots innovations are related to the struggle to maintain a viable sustainable sociotechnical space within a wider unsustainable regime. This translates into issues around securing funding, which in turn affects possibilities for institutionalisation and consolidating learning, managing organisational change, making effective links and networks with other societal actors, and diffusing oppositional ideas into wider society (Seyfang, 2009; Smith, 2006, 2007; Hielscher et al., 2013). Theory suggests three ways by which niches can influence the regime: they can enable replication of projects within the niche, bringing about aggregative changes through many small initiatives; they can enable constituent projects to grow in scale and attract more participants; and they can facilitate the translation of niche ideas into mainstream settings (Seyfang and Haxeltine, 2012).

Despite the growing body of work on niche development processes described above, there has been little exploration of niche formation and growth in the context of grassroots innovations, nor on the ways in which such niches might seek to gain wider influence on regimes (Smith, 2007; Longhurst, 2012; Hielscher et al., 2013 are rare exceptions). Additionally, traditional analyses have focused on national case studies of particular technologies. Thus, the literature has mainly considered supplyside, technological innovations in market settings, neglecting consumption-focussed social innovation in civil society (Grin et al., 2010). This paper therefore seeks to address this gap by exploring how niche development processes occur within an international grassroots innovation movement, using the empirical case of community currencies.

\section{Community currencies: grassroots innovations for sustainable development}

Community currencies are parallel exchange systems which have emerged from civil society all over the world over the last 30 years (Seyfang and Longhurst, 2013). Many are inspired by a 'green' strand of heterodox economic theory that challenges mainstream economic thought (Seyfang, 2009; Boyle and Simms, 2009), in particular often arguing that monetary reform and innovation is an overlooked area of economic policy (Ryan-Collins, 2010). They aim to deliver services and functionality that mainstream money 
cannot - such as keeping money circulating locally, providing liquidity in cash-poor areas to relieve unemployment and enable people to meet their needs, promoting active citizenship or volunteering, or encouraging greener behaviour (see Slay, 2011 for a review of evidence) and include initiatives such as Time Banks, Local Exchange Trading Schemes, 'trueque' barter markets and city-wide local currencies. These have been attracting increasing policy attention from governments keen to develop sustainable local economies and encourage community engagement - from official government support in Brazil (Melo, 2010) to the UK's Big Society agenda encouraging 'reciprocal exchange' and self-help (HM Government, 2011). Previous academic research has examined community currencies as initiatives to: tackle social exclusion and unemployment (Williams et al., 2001; Pearson, 2003; Seyfang, 2001b, 2002, 2003, 2004); localise economies and improve resilience (Graugaard, 2012; Gregory, 2009); build social capital and civic engagement (Seyfang and Smith, 2002; Collom, 2008); promote sustainable consumption (Briceno and Stagl, 2006; Seyfang, 2001a, 2006), and as forms of alternative social movements (North, 2007; Collom, 2011). However, there have been very few examinations of currencies as innovations (Douthwaite (2002) and Longhurst (2012) are rare examples), and this is where our contribution lies: to examine community currencies as innovative niches and understand how to diffuse their ideas and harness their potential.

In order to examine the niche processes occurring within the currency field, we undertook a global study of the scope, nature, objectives and development of major sustainability-focussed community currencies (see Seyfang and Longhurst, 2013). We drew on successful pre-existing working relationships inside the currency movement to access the latest information and further contacts, and we consulted a range of sources: existing empirical studies of currencies; practitioner literature; leading currency developers at an international workshop convened to share current knowledge and experience between currency groups; our advisory panel of academic and practitioner experts; and finally, we invited new research papers on 'the state of the art' in currency developments for a special issue of the International Journal of Community Currency Research (Longhurst and Seyfang, 2011). We examined the prevalence of different community types and their spread and development over time, and looked for evidence of niche-formation processes at work. A significant difficulty we encountered was the lack of reliable, up-to-date information on community currencies, even from national or international currency networks, and our analysis is based on the best quality information available. This necessarily includes claims made by key practitioners, and we have, where possible, sought triangulation to test their validity.

Currencies were categorised into four principal types (which simplifies the complexity of multiple local practices and objectives):

- Service Credits such as Time Banks/Time Dollars aim to build social capital, inclusion and cohesion by rewarding neighbourly support, social care and community-based activities. Participants earn a time credit for each hour spent helping someonethese credits can be saved up for future use, donated to someone else, or spent receiving services from other members.

- Mutual Exchange currencies such as Local Exchange Trading Scheme (LETS) are issued by users' spending: one person's credit equals another's debit to the system, accounts always sum to zero and the value of the currency is maintained by trust in other members to meet their commitments. LETS aims to be a general purpose money within a defined geographical area, offering additional liquidity and access to interest-free credit.

- Local Currencies are geographically-bounded currencies which circulate locally, increasing the local economic multiplier and supporting local businesses. Some are convertible to national currency, forming 'local exchange vouchers' redeemable only with participating businesses. Notable examples include the US Ithaca Hours, German Regiogeld, UK Transition currencies and Brazilian Community Banks.

- Barter Markets were first instigated in Argentina and expanded rapidly during their financial collapse. Individuals are issued with local 'creditos' as an interest-free loan. These are nonconvertible and are used to trade at regular markets. The Argentine networks have since declined, but in Venezuela and Mexico it has become closely associated with the solidarity economy, and in Quebec, Canada, with an environmental (reuse) focus.

Looking first at established community currency movements (i.e. with 5 or more active projects of a particular currency type in a country), we identified a total of 39 nationally-based currency groupings, in 23 countries, across six continents, representing a total of 3418 local projects (see Seyfang and Longhurst, 2013 for a full analysis). Fig. 1 illustrates the diffusion of the main currency types between countries, and how the field has grown over the last 40 years.

At the core of this international growth and diffusion has been the circulation of knowledge about both the rationale for community currencies and how they should be run, and a
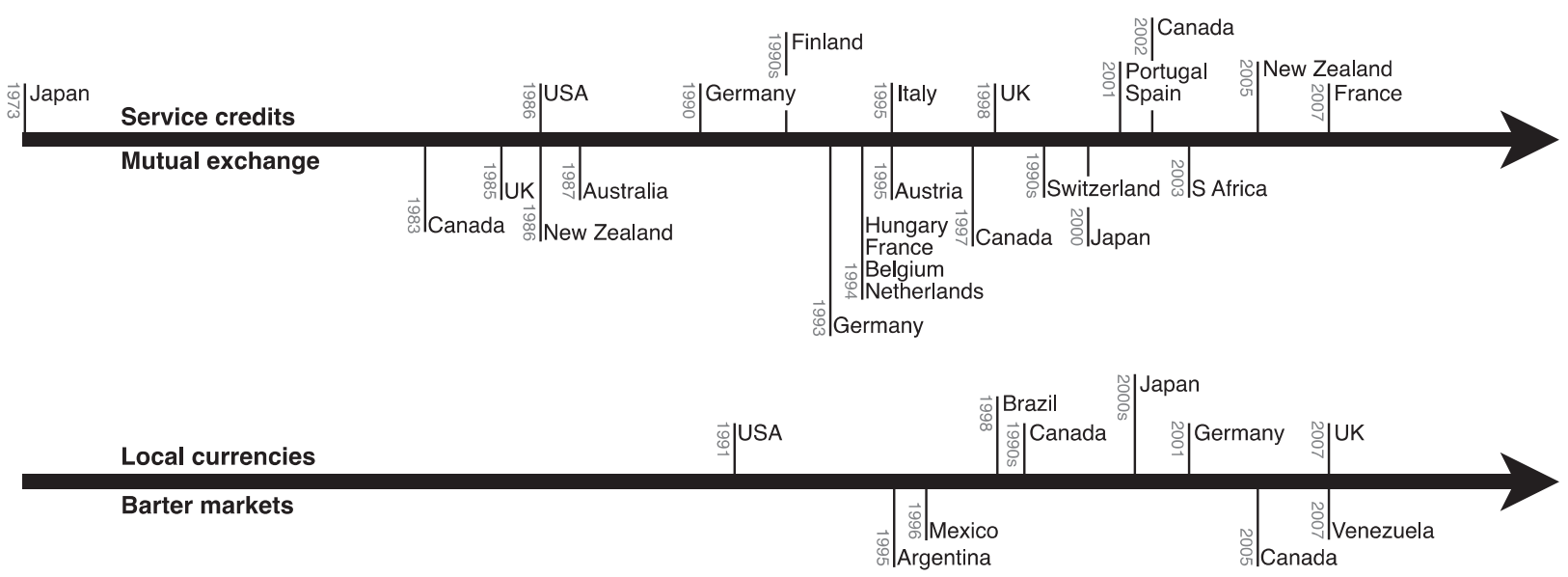

Fig. 1. The international diffusion of community currency types. 


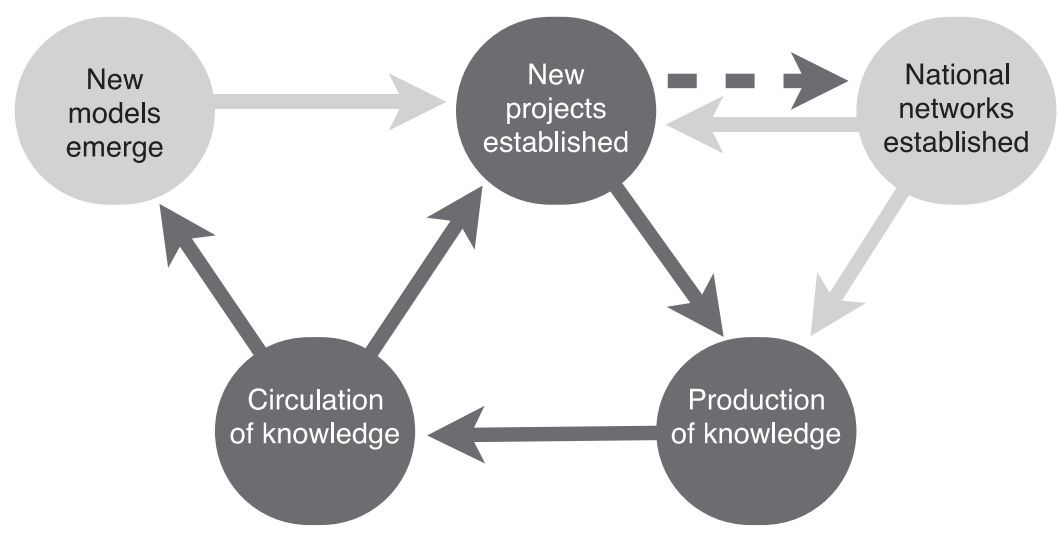

Fig. 2. Key knowledge-dissemination processes in the growth of the community currency field.

knowledge-based interpretation of the growth of the currency field is illustrated in Fig. 2. This information-circulation has occurred through media reports, key publications, conferences and workshops, lecture tours of currency innovators, and through various different networks and social movements. The spread of knowledge about community currencies leads to new projects emerging in novel contexts. For example, the anglophone countries who first established LETS attribute their origins to hearing a talk about the newly developed model at a New Economics conference in 1985. Subsequently, a UK LETS activist speaking at a French event inspired the first SEL (Systeme d'Exchange Locaux) system. In many cross-national cases like this, the new national type differs from the type that inspired it in some way, being adapted to local social, cultural and economic conditions. For example, the SEL places a stronger emphasis on social solidarity and is less oriented towards economic outcomes than the UK LETS that inspired it (Seyfang and Longhurst, 2013).

In some cases the diffusion of currency projects in a particular country has led to the emergence of national networking organisations. These play an important role in supporting the development of the currency movement: facilitating networking and learning between projects; aggregating knowledge; providing resources to assist with the establishing of new projects (handbooks, websites); acting as advocates for the currency type; and attempting to recruit new actors and supporters. Whether or not a national network emerges, the existence of currency projects leads to knowledge being produced about the currencies in the form of new books, research or articles in the media. This then feeds the further circulation of knowledge through both popular and specialist media channels, including some specific forms of knowledge infrastructure for gathering and disseminating this information: a global Complementary Currency Resource Centre (www.complementarycurrency.org); an online academic bibliography (www.cc-literature.de), a public- and movement-oriented magazine (www.ccmag.net) and a specialist academic journal (www.ijccr.net). Each of these is volunteer-run and contributes to the production and circulation of knowledge.

Additionally, new models emerge, inspired by an existing currency but adapting or hybridising into a new type of system. For example, the first example of local currencies detailed in Fig. 1 (the US-based Ithaca Hours system) was partly instigated by the failure of a LETS (mutual exchange) in Ithaca, New York, and went on to inspire many 'Hours'-type local currencies across North America (Jacob et al., 2004). Similarly, the first Argentinean Trueque (barter market) was modelled on LETS but then evolved by adapting some ideas from Ithaca Hours (Powell, 2002). This additional knowledge-practice loop within the development of the overall currency field has led to an increasing diversity of types, and further variations within types, over the last three decades.

While a wide range of actors are involved in currency projects on the ground, for example members of the public (as users), businesses, or governmental bodies as either sponsors or users, the processes shown in Fig. 2 have been driven by a number of key actors, whose roles are summarised in Table 1.

\section{Seeking niche development processes in the global community currency field}

Having outlined the overall shape, character and dynamics of the growing community currency field as a grassroots innovation for sustainability, we now examine the extent to which the niche theories set out in Section 2 are able to explain its development. We first consider aspects of the field's development which appear to confirm the predictions of niche theory (4.1), before going on to identify where the empirical case diverges from the theoretical model of niche-building (4.2).

\subsection{Evidence of niche-building processes}

Our analysis of the global community currency field suggests four areas where the niche-building processes identified in the Strategic Niche Management literature are evident and appear to be influential in the growth of the currency movement: in the role of national networks; networking more generally; creating shared visions and expectations; and in benefiting from regime crises as windows of opportunity.

Firstly, where a national network emerges there is clear evidence of the niche-building processes postulated by Geels and Raven (2006) and Geels and Deuten (2006). In such cases, a functioning and resourced national body can play a significant role in building networks, aggregating knowledge, supporting new projects and forging relationships with regime actors. These bodies help to create the more abstracted and transferrable 'global' level of a national-type currency niche from which knowledge and resources can flow back to the grassroots, supporting the establishment of new projects. In some cases there are processes of standardisation taking place, where the 'rules' relating to a particular system type are consolidated and codified into training materials, handbooks and so on. At this particular level of analysis, there seems to be a good fit between theory and practice.

Second, the importance of effective networking (both internally between existing projects and externally with wider groups of societal actors) is evident in currency-field growth. In addition to the network-building activities of formalised networks, 'new economics' organisations and writers have been at the forefront of 
Table 1

Significant actors in the development of the community currency field.

\begin{tabular}{|c|c|c|c|c|c|c|}
\hline \multirow[t]{2}{*}{ Type of actor } & \multirow[t]{2}{*}{ Details of role(s) played } & \multicolumn{5}{|l|}{ Stages } \\
\hline & & $\begin{array}{l}\text { Knowledge } \\
\text { circulation }\end{array}$ & $\begin{array}{l}\text { Establish } \\
\text { new } \\
\text { projects }\end{array}$ & $\begin{array}{l}\text { National } \\
\text { networks } \\
\text { established }\end{array}$ & $\begin{array}{l}\text { Production } \\
\text { of new } \\
\text { knowledge }\end{array}$ & $\begin{array}{l}\text { New } \\
\text { models } \\
\text { emerge }\end{array}$ \\
\hline $\begin{array}{l}\text { New economics think } \\
\text { tanks }\end{array}$ & $\begin{array}{l}\text { Promoting the rationale of currencies based on 'new economics' ideas; } \\
\text { establishing currency experiments; lobbying policymakers to support } \\
\text { currencies. E.g. nef (UK), Schumacher Society (USA), SANE (South Africa) }\end{array}$ & $\square$ & $\square$ & $\square$ & $\square$ & $\square$ \\
\hline Activists & $\begin{array}{l}\text { Pioneering activists are important as 'lead articulators' inspiring support for } \\
\text { a particular model and promoting it through their work; supporting national } \\
\text { networks. E.g. Edgar Cahn, Michael Linton, João Joaquim de Melo Neto } \\
\text { Segundo, Christian Gelleri }\end{array}$ & $\square$ & $\square$ & $\square$ & $\square$ & $\square$ \\
\hline $\begin{array}{l}\text { National networking } \\
\text { bodies }\end{array}$ & $\begin{array}{l}\text { Supporting the development of existing and new projects; networking; } \\
\text { consolidating knowledge; advocacy. E.g. Time Banks USA, LETSLink UK, } \\
\text { Palmas Institute (Brazil), Regiogeld (Germany) }\end{array}$ & $\square$ & $\square$ & & $\square$ & \\
\hline Specialist intermediaries & $\begin{array}{l}\text { Providing active support for the development of new systems; providing } \\
\text { training and consultancy to currency users, especially local government, } \\
\text { NGOs and businesses. E.g. Qoin, Value for People, STRO }\end{array}$ & $\square$ & $\square$ & & $\square$ & $\square$ \\
\hline $\begin{array}{l}\text { Other NGOS/Social } \\
\text { movements }\end{array}$ & $\begin{array}{l}\text { Experimenting with currencies as tools to meet their objectives. E.g. the } \\
\text { Transition Town movement (Transition currencies), PAR (Truque), } \\
\text { Anthroposophy and Freigeld monetary reform movements (Regiogeld) }\end{array}$ & $\square$ & $\square$ & & $\square$ & $\square$ \\
\hline Academics/Writers & $\begin{array}{l}\text { Producing knowledge about currency projects and movements; evaluating } \\
\text { currency projects and deriving best practice; disseminating knowledge } \\
\text { through popular and specialist media. E.g. IJCCR, Tom Greco, David Boyle, } \\
\text { Bernard Lietaer, Magrit Kennedy }\end{array}$ & $\square$ & & & $\square$ & \\
\hline Media & $\begin{array}{l}\text { Spreading the idea of currencies thorugh both specialist and general media. } \\
\text { E.g. CC-mag, newspapers, magazines and television programmes. }\end{array}$ & $\square$ & & & $\square$ & \\
\hline
\end{tabular}

promoting community currency models via their own international networks as well as through environmental and monetary reform movements. There are few examples of formal international currency networks, however informal networking amongst activists and currency developers is established and maintained via periodic conferences and workshops as well as via social media.

The third area of congruence between niche theory and evidence from the currency field is the importance of visions and expectations. The SNM literature claims that effective niches require shared visions and robust expectations both within a niche (for recruiting and retaining participants) and with external actors (for providing support), yet this can be problematic in experiments when performance is sub-optimal. This tension has been captured in some of the work on 'promise-requirement' and 'hypedisappointment' cycles (e.g. Verbong et al., 2008) and has been noted within the academic literature on currencies (Aldridge and Patterson, 2002; Stott and Hodges, 1996). Our data confirms that expectation-management is a significant part of the currency development process at multiple levels. One currency developer felt that managing the (performance and outcome-related) expectations of stakeholders was one of the biggest challenges facing currency projects. These processes took place at two different levels. The first was amongst partners at the project level:

It's very challenging because people have expectations that are quite often unrealistic and that is a big part of managing the project successfully and that is really difficult. My role is strategic development and stakeholder relations. I talk to them as often as I can.

Interview with currency developer 1

Thus, currency projects (like other forms of grassroots innovation) can be understood as attempts to manage a range of different user and stakeholder group expectations about the ability of the currency to fulfil a range of distinct (and maybe competing) functions (Longhurst, 2012). To maintain and develop the project the currency activists or managers need to balance these different expectations at the local level. These challenges were also evident at the 'higher' level of national type, where currency activists might be seeking support either for their own organisation or for the diffusion of the model. As Strategic Niche Management predicts, the management of such expectations becomes a critical factor in maintaining the flow of resources. One currency developer who received funding from policy networks provides a contemporary example:

Because of the interest and the funding [...] we are feeling a huge expectation about what can be delivered...As an organization I think that managing expectations of central government and funders is more difficult than it has ever been, partly because they are so excited about it [...] this is obviously really, really, good but it is a double edged sword I think.

Interview with currency developer 2

The fourth aspect of niche theory that seems relevant to explaining the currency field's development is the importance of regime crises as opportunities for currency growth. Currency activists often work opportunistically to exploit the windows of opportunity that are created by regime problems and crises, and aligning with a particular policy agenda can lead to resource flows in favour of niche development at the national level. However, an associated risk is that such resources can easily be diverted away should the policy agenda move on, or if the currency model fails to deliver on the expectations of functionality that have been raised with policy makers.

Historically, we observe periods of currency flourishing at times of economic and social crisis such as during the Great Depression, and the Argentinean economic collapse of the early 2000s (North, 2007). There is evidence of a new wave of currency activism and experimentation in response to the ongoing global economic crisis and the austerity policies it has engendered: new exchange systems are emerging in countries such as Spain and Greece (Sotiropoulou, 2011) and in the UK where there is policy interest in community-led alternatives to public service provision through the Big Society policy agenda (Boyle, 2011). This, when combined with lobbying and the existence of other visible examples can have a powerful effect, as one currency developer explains:

The policy climate has been right. People are being forced to think about new ways of using limited resources. I think that 
there has been a fair amount of lobbying too. [...] There appears to be an opening at higher policy level for talking about these kinds of projects. NESTA [a UK innovation agency] got on the back of it and have pushed it all over the place. It has been a mixture of things. The change of government, they got into power and ... were looking for ideas around the Big Society. . all those strands have come together at the same time. Interview with currency developer 2

\subsection{Disjunction between niche theory and the community currency} field

Whilst the previous section identified a reasonable fit between the theory and evidence from the field, there are also some interesting anomalies. We identify three main aspects of the community currency field's development which contrast markedly with the niche-building processes described in the Strategic Niche Management literature: a growing diversity of the field; complex regime interactions; and the lack of formal learning processes.

\subsubsection{Increasing diversity of the field}

Niche theory predicts that as a novel technology grows there should be an increasing degree of consolidation and convergence leading to the emergence of a stabilised field and 'technological trajectory' where there are well established rules (Geels and Raven, 2006). At first glance there is a growing currency field where the constituent projects share a core similarity as novel socio-technical configurations of exchange. Indeed much of the literature treats them as a single field or movement (e.g. Blanc, 2010). However, our research suggests that as this field has developed it has experienced ever-increasing degrees of fragmentation, complexity and branching. Despite some activity and institution building at the international level, there is no momentum towards unification of practices, expectations, standards-setting and mobilisation of resources. This challenges the assumption that technological niches tend to follow a trajectory towards increasing consolidation and conformity of knowledge (ibid). It may be that community currencies are still, in longer historical perspective, an immature and nascent innovation. Or it could be, as we will argue below, that community currencies (and grassroots innovations) are fundamentally different to those described by the current innovation niche literature.
Fig. 3 depicts a simplified version of the field, focusing on just two currency types for clarity. As discussed in Section 4.1, the national level is where we see significant knowledge-aggregation processes, particularly where national networking organisations have been able to establish themselves. However, even at this level there are examples of increasing fragmentation over time. For example, in the case of timebanking in the UK, a number of new variations have emerged in recent years, despite the existence of a stable national networking body. Arguably, regime engagement is strongest at the national level, with policy actors and NGOs helping to translate community currencies into policy-relevant forms. There have been some attempts at building formal relationships between different national types that are based on similar models (e.g. between Time Banks UK and USA) but most relationships at this level are informal and sporadic, for example, between different barter systems in South America or LETS in Europe. Collaboration at this level appears to be primarily funding-driven, such as the 'importing' of LETS into Hungary, funded by the British Council (Jelínek et al., 2012) or the recently launched EU-funded Community Currencies in Action project (http://communitycurrenciesinaction.eu/). At the level of the whole community currency field there are some institutions for co-ordination and consolidation such as the Complementary Currency Resource Centre and the IJCCR academic journal. However, these are fundamentally about the dissemination of knowledge rather than an attempt at aggregation, unification or standardisation [an exception is the online CC-Mag which aims to "build the movement through supporting internal coherence” (www.ccmag.net)].

We found three reasons why the currency field appears to have grown in complexity, and these relate the nature of the innovation itself. Firstly, the diffusion of some system types has been assisted by the fact that the currencies are relatively 'low-tech', meaning they are cheap and easy to get established (although not necessarily to sustain in the longer term). Furthermore, like other grassroots innovations, there is a strong 'open source' ethic to the movement, meaning that the knowledge relating to system establishment is easily available, assisting the spread of systems (Ornetzeder and Rohracher, in this issue). An interesting example of this phenomenon can be found within the UK LETS movements of the 1990s. Here there was a conflict between two competing models: the proprietary and controlled LETSystem designed by Michael Linton ('inventor' of the original LETS model) and the

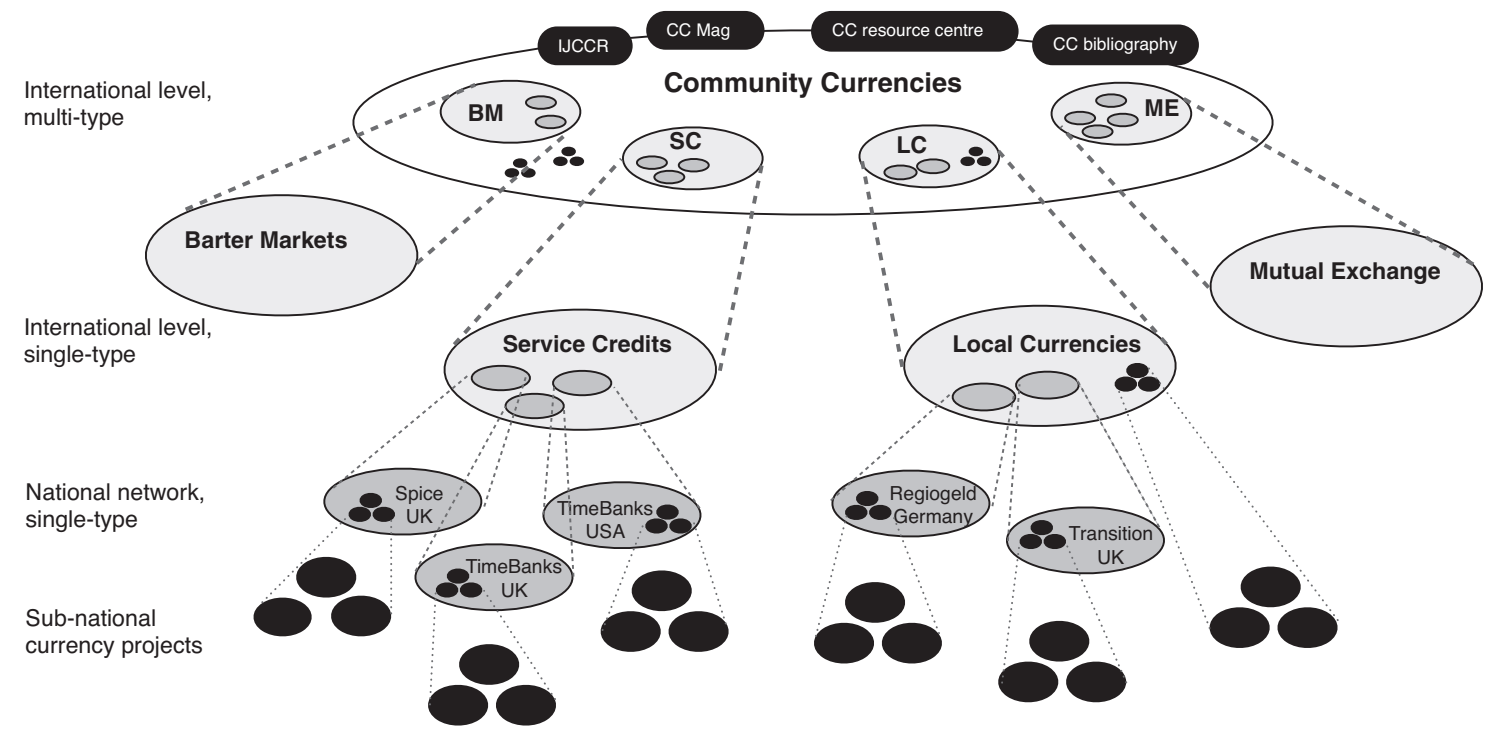

Fig. 3. The community currency field. 
LETScheme model developed by LETSLink UK which was more flexible and open to user innovation; the latter diffused in far greater numbers.

Secondly, as grassroots innovations, currency projects tend to respond to a specific social or ecological problem. As the field has developed, projects have emerged with a range of different objectives: economic localisation; equitable working structures; financial inclusion; building social capital and cohesion; promoting sustainable consumption; and encouraging active citizenship (Kent, 2005; Greco, 2001; Robertson, 1999; Douthwaite, 1996; Lietaer, 2001). While some of these are motivated by a critique of the mainstream monetary system, others address more specific problems or goals. The increasing application of currencies to new problems or domains has partly driven the development of new system types, leading to disagreements over functionality and purpose both within and between systems, and so contributing to the field's fragmentation. Conflict can therefore arise when the problem frame which the currency is addressing is derived from strong values or political beliefs. For example, the Argentinean Trueque movement was split by two factions who had competing ideas about the purpose of the currency, either as an anti-poverty tool for the unemployed, or as an alternative to capitalism (North, 2007). The experiences of the Trueque have some parallels with Hess' (2005) hypothesis of 'object conflicts' which states that as established industries absorb innovations from civil society, the field becomes diversified and conflict emerges between actors. Other currencies have also faced internal disagreements over the extent to which they should engage with mainstream policy and business actors, for example the French SEL.

Thirdly, and deriving from this, the community currency field therefore constitutes of a range of overlapping social movements, non-governmental organisations, activists and projects, often with fundamentally different ideological visions and goals. It would be an oversimplification to assume these different actors share a common cause, despite their frequent and significant interactions. Indeed competition between different system types can be exacerbated by competition over resources. In other words, in the case of grassroots innovation there is a much greater diversity of values and beliefs that motivate the innovation and which play an important role in explaining niche dynamics (Ornetzeder and Rohracher, in this issue). This is in contrast to market based innovation where the primary objective, in most cases, is to generate a financial return. Theories of niche development assume that technologies define socio-technical configurations, and so the literature does not deal satisfactorily with the complexities of differently aligned value-based initiatives which share similar technologies. This indicates a technological-bias in the way niche theory might be applied to grassroots innovations, by assuming that common technologies imply common interests and coherent visions. Existing theory therefore privileges the technological over the social, but our research with currencies suggests that this neglects critical factors affecting the ability of influential civil society niches to form (i.e. a lack of common interests and vision).

\subsubsection{Complex regime interactions}

The variety of problems to which currencies are addressed raises a second, perhaps more fundamental, obstacle when applying niche analysis to community currencies: the challenge of identifying which regime the niche aims to transform or replace. As noted above, there can be a range of motivations behind such projects and a variety of intended purposes. For example, local currencies, barter markets and mutual credit currencies often aim to build new financial infrastructures (niche practices are democratic control of the money system, anti-expansionist money, self-regulation based on trust and localised economies) to complement or replace the money/banking regime (global institutions, growth-based, banks issue money). In contrast, service credits aim to improve social capital, civic engagement and wellbeing, and opportunities for such systems have arisen due to tensions in the regime of social care provision, particularly those based on professionalised providers and passive users defined by their needs. This complexity can be further complicated within particular currency types, where different projects engage with multiple regimes. For example service credits have been applied across a range of domains such as health, education, criminal justice and community development. Given that they 'face' different regimes, the challenge of unifying currencies - or even just service credits, in this instance - around common goals is even more problematic, in particular when it comes to efforts to lobby for policy support and translate elements of the niche practices into (multiple) incumbent regimes. The case of currencies suggests that for grassroots innovations, the question of 'which regime' is perhaps more fundamental and problematic than might first appear.

In its current form, niche theory does not seem to be able to account for or anticipate the complexity of regime interactions in the community currency case. There has been some work on market-based 'niche accumulation' where a new technology establishes itself by gaining a foothold in a number of niche markets (Raven, 2007). Similarly, there has been some work on regimes crossing (e.g. Konrad et al., 2008; Raven and Verbong, 2009) where a technology crosses from one regime to another. However, the existing literature generally assumes relatively simple regime interactions, both in terms of their number and their definition (e.g. energy or waste). However, are 'health' or 'education' - the regimes which currencies often seek to change - the same 'kind' of socio-technical systems as transport or water? While they may not have the same underlying technical infrastructure, they do still consist of socio-technical assemblages that are shaped and held together by sets of complex rules. This issue is even more pertinent for the domain of the economic and financial system towards which many currency systems are orientated. To some degree the economic system has been 'black-boxed' by the sustainability transitions literature, which has close affinities with ecological modernisation (Shove and Walker, 2007). Assumptions of a functioning capitalist system would appear to underpin much of the theoretical work, but the implication of this has not been explored properly. Alternatively, economic problems also can be characterised as forms of landscape pressure that destabilise regimes (Geels and Schot, 2010: 70). The economic system's ambiguous role suggests that distinctions between regimes and landscapes can be blurred (Hess, 2012) and require further attention. Furthermore, like energy, the economy is a regime which cuts across many others, and more work is needed on how regimes interconnect (Hargreaves et al., 2013). This is particularly so in the case of grassroots innovations where the objective is often not to completely displace the incumbent regime but to build "parallel public infrastructure [that] aims to provide necessary systems that individuals can't provide themselves" (Darley et al., 2006 unpaginated quoted in Hopkins, 2006: 42).

\subsubsection{The role of knowledge and learning}

The third area where there appears to be a disjunction between niche theory and the development of the currency field relates to the role of learning. Although the currency field's growth has been dependent on the circulation of currency knowledge [dissemination], there was no substantial evidence of that this was dependent on formalised learning process, nor the emergence of standardised rules and codified knowledge at the field level [aggregation], and it is not possible to ascertain what impact better learning processes would have on the overall trajectory of the niche. Douthwaite has argued that currency activists have found learning difficult because they lack good mechanisms to encourage and capitalise 
on 'user learning selection' $(2002,161)$ (the way users' choices influence an innovation's future development). In other words, currencies, and other grassroots innovations, struggle to capture learning because they unfold in a social environment that is unpredictable and where 'tests' are often unrepeatable. Furthermore, it would appear that currency activists depend on 'learning by doing' because they lack the resources to implement more formalised learning processes. This knowledge is complemented by academic work, ad-hoc evaluations and in some cases, national currency networks are able to capture learning from their member projects and consolidate it in the form of handbooks or best practice guides. However, these organisations often struggle to fulfil this function and there appears to be little knowledge transfer between different currency types. Overall, we would argue that in contradiction to niche theory, learning processes have not been linear or cumulative and formal learning processes do not appear to be a pre-requisite for the growth of the wider field.

Consequently our analysis suggests that resource acquisition is critical to support the learning role of intermediaries and other actors. For example, national networks are most effective at diffusing new projects when they are well resourced and able to fulfil niche aggregation functions. This is not to say that community currencies cannot diffuse without a national network, but there are clear examples of where well-resourced national networks are able to support the spread of a particular model such as Banco Palmas in Brazil. The lack of resources to support learning processes is part of a wider issue with the financial viability of grassroots innovations, and the inability of currency projects to sustain themselves is also clearly a common problem. Many currencies are social economy initiatives reliant on volunteers and short term funding, leaving them fragile and vulnerable to changes in funding priorities or public attention (Seyfang, 2009). As nonmarket innovations they are unable to generate a surplus to sustain themselves through market transactions or from investors seeking a future financial return; they need to find other ways to recover their costs and provide resources with which to develop and grow. Thus this case supports Geels and Schott's (2010) argument that Strategic Niche Management has underplayed the significance of resources, we can say that this is even more critical in the case of civil society innovations.

\section{Conclusions}

This paper has undertaken an analysis of the growing international community currencies movement to explore the extent to which niche theories of radical green innovation diffusion developed for market contexts are relevant to the experiences of civil society-led, grassroots innovations in the social economy. It has revealed that some of the niche-building processes considered essential by sustainability transitions and Strategic Niche Management theory are being performed at a range of scales, and existing theories of market-based innovation have some empirical purchase, but they do not fully explain the processes of diffusion that have led to the emergence of this field.

Niche-building activities identified in the literature were most evident at the 'national type' level, where intermediary actors perform a range of roles that theory suggests lead to the development of influential niches. At this level we also found that, in keeping with recent theoretical propositions, regime interactions have an influence on niche development, particularly in terms of providing critical financial and other support, and creating opportunities for niche growth through aligning with current policy interests (or responding to regime crises) and the opening of 'policy windows' (Kingdon, 2011). The ability of intermediaries to take advantage of such opportunities appears to be very much linked to their ability to manage the expectations of stakeholders and other significant actors. Strategic Niche Management theories would therefore indicate that investing in learning, consolidation and networking at the national currency-type level (where resources can best be levered from policy actors) is the most promising approach for further niche development.

However, the currencies case does not entirely fit with the predictions of niche theory, and so problematises a number of areas in the niche literature (attenuating recommendations for policy and practice to harness the potential of these innovations) which require further examination. Firstly, the field has developed despite relatively weak learning processes (which may undermine the potential of currency experiments, but has not prevented the overall growth of the field). Secondly, the straightforward alignments between innovative niches and regimes which theory seems to expect do not always exist. A single currency 'niche' (for example at the national type level) can potentially engage with a number of different regimes and in some cases, where the regime is 'the economy' or 'monetary system' it is not clear how it can be conceptualised. Thirdly, the field as a whole has not developed in the way that niche theory predicts: instead of consolidation and coherence we witness a greater degree of fragmentation and variety. This can be explained, we argue, because community currencies are a fundamentally different form of innovation to the market-based sociotechnical innovations from which niche theory has been derived. As innovations in social institutions, currencies are not only easier to replicate and adapt than technological innovations requiring capital investment, they are also more explicitly entwined in politics and values. Peer-to-peer knowledge dissemination [rather than aggregation, consolidation and standardisation] has driven the growth of the movement. Consequently, these characteristics attenuate the niche theorydriven recommendations made previously, not least because they are applied here in a context of scarce funding, largely voluntaristic input, and diverse values and objectives. We conclude that some of the niche-building activities that theory says is required, are not critical for grassroots innovations movement growth, and the characteristics of these innovations may preclude further gestation of an effective, influential niche.

Our empirical analysis therefore highlights the complexity of grassroots innovations' diffusion, and we suggest further theoretical work is required to fully understand how grassroots innovations might influence the trajectory of socio-technical systems. One possible avenue for further research is to undertake comparative analyses of the national-type 'niches' to explore how they support currency diffusion. A second area of research would be to explore the dynamics of the fields of other grassroots innovations to see whether they exhibit the same patterns of fragmentation as evidenced here. Thirdly, the complex relationship between grassroots innovation niches and regimes could be examined by identifying historical examples of community currencies which have successfully shifted system dynamics, to clarify how these civil society innovations can be theorised in relation to incumbent systems. This would establish whether sociotechnical transitions resulting from grassroots innovations follow the same trajectories as those postulated by niche theory, or whether different conceptual and theoretical tools are needed. Comparative work such as this would also help to address another important question that remains unanswered: the extent to which community currencies are representative of grassroots innovations in general.

In conclusion, our niche analysis of the community currency field has revealed where existing niche literature has some explanatory purchase on the empirical case of grassroots innovations, and some areas where it falls short of adequately explaining how these civil society-led innovations grow and develop. It is our 
hope that in examining grassroots innovations in this way, and identifying promising areas of practice and further research, we can contribute to a deeper understanding of the processes involved in harnessing the potential of these innovations for sustainability.

\section{Acknowledgements}

The authors are grateful for the support of the Leverhulme Trust in funding this research (Harnessing Grassroots Innovations: Complementary Currencies and Sustainability, project ref F/00 204/AM), and to all the practitioners who participated by sharing their expertise and knowledge. We acknowledge the contributions of colleagues to ongoing discussions on grassroots innovations, which have informed this paper, in particular: Adrian Smith, Tom Hargreaves and Sabine Hielscher, and we are grateful for comments made by participants of the Grassroots Innovations for Sustainability workshop (May 16-18, 2012, University of Sussex). Thanks also for the constructive comments made by the two anonymous reviewers. Any errors or omissions remain the authors' responsibility.

\section{References}

Aldridge, T., Patterson, A., 2002. LETS get real: constraints on the development of local exchange trading systems. Area 34 (4), 370-381.

Avelino, F., Kunze, I., 2009. Exploring the transition potential of the ecovillage movement. In: European Conference on Sustainability Transitions: Dynamics and Governance of Transitions to Sustainability, June 4-5, 2009, Amsterdam, The Netherlands.

Blanc, J., 2010. Community and complementarty currencies. In: Hart, K., Laville, J.L., Cattani, A.D. (Eds.), The Human Economy. Polity Press, Cambridge, pp. 303-324.

Blanc, J., 2012. Thirty years of community and complementary currencies. Editorial for the special issue. International Journal of Community Currency Research 16, D1-D4., www.ijccr.net.

Boyle D., 2011. More Than Money: Platforms for Exchange and Reciprocity in Public Services. NESTA, London.

Boyle, D., Simms, A., 2009. The New Economics. Earthscan, London.

Briceno, T., Stagl, S., 2006. The role of social processes for sustainable consumption. Journal of Cleaner Production 14 (17), 1541-1551.

Church, C., Elster, J., 2002. The Quiet Revolution. Shell Better Britain, Birmingham.

Collom, E., 2008. Engagement of the elderly in time banking: the potential for social capital generation in an aging society. Journal of Aging and Social Policy 20 (4), 414-436.

Collom, E., 2011. Motivations and differential participation in a community currency system: the dynamics within a local social movement organization. Sociological Forum 26 (1), 144-168.

Collom, E., Lasker, J.N., Kyriacou, C., 2012. Equal Time, Equal Value. Ashgate, Farnham.

Darley, J., Room, D., Rich, C., 2006. Relocalise Now! Getting Ready for Climate Change and the End of Cheap Oil. Post Carbon Institute New Society Publishers, Gabriola Island

DEFRA, 2012. Shaping our Future: Implementation Plan for Government Commitments. DEFRA, London.

Douthwaite, B., 2002. Enabling Innovation. Zed Books, London.

Douthwaite, R., 1996. Short Circuit: Strengthening Local Economies for Security in an Unstable World. Green Books, Totnes, UK.

Geels, F.W., 2002. Technology transitions as evolutionary reconfiguration processes: a multi-level perspective and a case study. Research Policy 28 (5), 469-488.

Geels, F., 2005. The dynamics of transitions in socio-technical systems: A multilevel analysis of the transition pathway from horse-drawn carriages to automobiles. Technology Analysis and Strategic Management 17 (4), $445-476$.

Geels, F., 2006. The hygenic transition from cesspools to sewer systems (18401930): the dynamics of regime transformation. Research Policy 35 (7), 1069-1082.

Geels, F., Deuten, J.J., 2006. Local and global dynamics in technological development: a socio-cognitive perspective on knowledge flows and lessons from reinforced concrete. Science and Public Policy 33 (4), 265-275.

Geels, F., Raven, R., 2006. Non-linearity and expectations in niche-development trajectories: ups and downs in Dutch biogas development (1973-2003). Technological Analysis and Strategic Management 18 (3/4), 375-392.

Geels, F., Schot, J., 2007. Typology of sociotechnical transition pathways. Research Policy 36, 399-417.

Geels, F.W., Schot, J., 2010. The dynamics of transitions: a socio-technical perspective. In: Grin, J., Rotmans, J., Schot, J. (Eds.), Transitions to Sustainable Development. Routledge, London, pp. 11-101.
Georg, S., 1999. The social shaping of household consumption. Ecological Economics 28, 455-466.

Graugaard, J., 2012. A tool for building community resilience? A case study of the Lewes Pound. Local Environment 17 (2), 243-260.

Greco, T., 2001. Money: Understanding and Creating Alternatives to Legal Tender. Chelsea Green, Vermont.

Gregory, L., 2009. Spending time locally: the benefit of time banks for local economies. Local Economy 24 (4), 323-333.

Grin, J., Rotmans, J., Schot, J.W., 2010. Transitions to Sustainable Development: New Directions in the Study of Long Term Transformative Change. Routledge, Abingdon $397 \mathrm{pp}$.

Hargreaves, T., Longhurst, N., Seyfang, G., 2013. Up, down, round and round: connecting regimes and practices in innovation for sustainability. Environment and Planning A 45 (2), 402-420.

Hess, D., 2005. Technology- and product-oriented movements: approximating social movements studies and science and technology studies. Science, Technology and Human Values 30 (4), 515-535.

Hess, D., 2007. Alternative Pathways in Science and Industry: Activism: Innovation and the Environment in an Era of Globalization. MIT Press, Cambridge MA

Hess D., 2012. Transitions, societal change and countervailing power: finance, democracy and green energy. In: United States' paper presented at the Grassroots Innovations for Sustainability international workshop, May 16-18, University of Sussex.

Hielscher, S., Seyfang, G., Smith, A., 2013. Grassroots innovations for sustainable energy: exploring niche development processes among community energy initiatives. In: Cohen, M., Brown, H., Vergragt, P. (Eds.), Innovations in Sustainable Consumption: New Economics, Socio-technical Transitions, and Social Practices. Edward Elgar, pp. 133-158.

Hoogma, R., Kemp, R., Schot, J., Truffer, B., 2002. Experimenting for Sustainable Transport. Spon Press, London.

HM Government, 2011. Giving White Paper. HMSO, London.

Hopkins, R. (2006). Energy descent pathways: evaluating potential responses to peak oil. Masters dissertation. Plymouth, University of Plymouth.

Jackson, T., 2009. Prosperity Without Growth. Earthscan, London.

Jacob, J., Brinkerhoff, M., Jocvic, E., Wheatley, G., 2004. HOUR town: Paul Glover and the genesis and evolution of Ithaca hours. Interational Journal of Community Currency Research 8, 29-41.

Jelínek, P., Szalay, Z.E., Konečný, A., 2012. Local exchange trade systems in central European post communist countries. International Journal of Community Currency Research 16 (D), 116-123.

Kemp, R., Schot, J., Hoogma, R., 1998. Regime shifts to sustainability through processes of niche formation: the approach of strategic niche management Technology Analysis and Strategic Management 10, 175-198.

Kent, K., 2005. Healthy Money. In: Healthy Planet: Developing Sustainability Through New Money Systems, Craig Potton Publishing, Nelson NZ.

Kingdon, J.W., 2011. Agendas, Alternatives, and Public Policies, 2nd edition. Longman, London.

Konrad, K., Truffer, B., Voss, J., 2008. Multi-regime dynamics in the analysis of sectoral transformations potentials: evidence from German utility sectors. Journal of Cleaner Production 16, 1190-1202.

Lietaer, B., 2001. The Future of Money: Creating new wealth, work and a wiser world. Century, London.

Longhurst N., 2012. The Totnes Pound: A grassroots technological niche. In: Davies, A. (Ed.), Enterpising Communities: Grassroots Sustainability Innovations. Bingley, Emerald, pp. 163-188.

Longhurst, N., Seyfang, G., 2011. Complementary currencies: state of the art, special issue. International Journal of Community Currency Research 15, , www.ijccr.net.

McCarthy, K., 2010. The Ecology of Innovation. RSA, London.

Melo, J., 2010. Associative community banks in Brazil. Working USA: The Journal of Labor and Society 13, 61-76.

Mellor, M., 2010. The Future of Money. Pluto Press, London.

Mulgan, G., 2006. Social Silicon Valleys: A manifesto for social innovation. Young Foundation, London.

NESTA, 2009. People-Powered Responses to Climate Change: Mapping CommunityLed proposals to NESTA's Big Green Challenge. NESTA, London.

North, P., 2007. Money and Liberation. London, University of Minnesota Press.

Ornetzeder, M., Rohracher, H. Of solar collectors, wind power, and car sharing: comparing and understanding successful cases of grassroots innovations. Global Environmental Change, in this issue.

Pearson, R., 2003. Argentina's Barter networks: new currency for new Times. Bulletin of Latin American Research 22 (2), 214-230.

Powell, J. (2002) Petty capitalism, perfecting capitalism or post-capitalism? Lessons from the Argentinian Barter Network, ORPAS - Institute of Social Studies, The Hague, Working Paper 357.

Raven, R. (2005) Strategic Niche Management for biomass. PhD Thesis, Eindhoven, Technische Universiteit Eindhoven.

Raven, R., 2007. Niche accumulation and hybridisation strategies in transition processes towards a sustainable energy system: an assessment of differences and pitfalls. Energy Policy 35, 2390-2400.

Raven, R., Verbong, G., 2009. Boundary crossing innovations: case studies from the energy domain. Technology in Society 31, 85-93.

Robertson, J., 1999. The New Economics of Sustainable Development: A Briefing for Policymakers. Kogan Page, London.

Ryan-Collins, J., 2010. Not so mickey mouse: lessons in the nature of modern money from complementary monetary innovations. Economic Sociology European Electronic Newsletter 12 (1), 58-67. 
G Mode

JGEC-1083; No. of Pages 11

G. Seyfang, N. Longhurst/Global Environmental Change xxx (2013) $x x x-x x x$

11

Cane, C., 2002. Willing consumers - or locked-in? Policies for a sustainable consumption. Ecological Economics 42, 273-287.

Schot, J.W., Hoogma, R., Elzen, B., 1994. Strategies for shifting technological systems. The case of the automobile system. Futures 26 (10), 1060-1076.

Seyfang, G., 2001a. Community currencies: small change for a green economy. Environment and Planning A 33, 975-996.

Seyfang, G., 2001b. Working for the Fenland dollar: An evaluation of Local Exchange Trading Schemes (LETS) as an informal employment strategy to tackle social exclusion. Work, Employment and Society 15 (3), 581-593.

Seyfang G., 2002. Tackling social exclusion with community currencies: learning from LETS to timebanks. International Journal of Complementary Currency Research 6, , In: www.ijccr.net.

Seyfang, G., 2003. Growing cohesive communities, one favour at a time: social exclusion, active citizenship and time banks. International Journal of Urban and Regional Research 27 (3), 699-706.

Seyfang, G., 2004. Working outside the box: community currencies, time banks and social inclusion. Journal of Social Policy 33 (1), 49-71.

Seyfang, G., 2006. New institutions for sustainable consumption: an evaluation of community currencies. Regional Studies 40 (7), 781-791.

Seyfang, G., 2009. The New Economics of Sustainable Consumption: Seeds of Change. Basingstoke, Palgrave MacMillan.

Seyfang, G., Smith, A., 2007. Grassroots innovations for sustainable development: towards a new research and policy agenda. Environmental Politics 16 (4), 584-603.

Seyfang, G., Haxeltine, A., 2012. Growing grassroots innovations: exploring the role of community-based initiatives in sustainable energy transitions. Environment and Planning C 30 (3), 381-400.

Seyfang, G., Longhurst, N., 2013. Growing green money? Mapping grassroots currencies for sustainable development. Ecological Economics 86, 65-77.

Seyfang, G., Smith, K., 2002. The Time of our Lives: Using Time Banking for Neighbourhood Renewal and Community Capacity-Building. New Economics Foundation, London.

Shove, E., Walker, G., 2007. CAUTION! Transitions ahead: politics, practice and sustainable transition management Environment and Planning A 39, 763-770.
Slay, J., 2011. More Than Money. NESTA, London.

Smith, A., 2006. Green niches in sustainable development: the case of organic food in the United Kingdom. Environment and Planning C 24, 439-458.

Smith, A., 2007. Translating sustainabilities between green niches and sociotechnical regimes. Technology Analysis and Strategic Management 19 (4), 427-434.

Smith, A., Raven, R., 2012. What is protective space? Reconsidering niches in transitions to sustainability. Research Policy 41 (6), 1025-1036.

Smith, A., Stirling, A., Berkhout, F., 2005. The governance of sustainable sociotechnical transitions. Research Policy 34, 1491-1510.

Smith, A., Voss, J.-P., Grin, J., 2010. Innovation studies and sustainability transitions: the allure of the multi-level perspective and its challenges. Research Policy 39 (4), 435-448.

Sotiropoulou I., 2011. Alternative Exchange Systems in Contemporary Greece. International Journal of Community Currency Research 15, D27-D31., In: www.ijccr.net.

Spratt, S., Simms, A., Neitzert, E., Ryan-Collins, J., 2009. The Great Transition. New Economics Foundation, London.

Stott, M., Hodges, J., 1996. Local exchange and trading schemes: never knowingly undersold? Local Economy 11 (3), 266-268.

UKERC [UK Energy Research Centre], 2009. Making the Transition to a Secure and Low-Carbon Energy System: Synthesis Report. UK Energy Research Centre, London.

Verbong, G., Geeks, F.W., Raven, R., 2008. Multi-niche analysis of dynamics and policies in Dutch renewable energy innovation journeys (1970-2006): hypecycles, closed networks and technology-focused learning. Technology Analysis and Strategic Management 20 (5), 555-573.

Williams, C.C., Aldridge, T., Tooke, J., Lee, R., Leyshon, A., Thrift, N., 2001. Bridges into Work: An Evaluation of Local Exchange Trading Schemes (LETS). Policy Press, Bristol.

Witkamp, M., Raven, R., Royakkers, L., 2011. Strategic niche management of social innovations: the case of social entrepreneurship. Technology Analysis and Strategic Management 23 (6), 667-681.

Please cite this article in press as: Seyfang, G., Longhurst, N., Desperately seeking niches: Grassroots innovations and niche development in the community currency field. Global Environ. Change (2013), http://dx.doi.org/10.1016/j.gloenvcha.2013.02.007 